\title{
Effects of calcium supply on soybean plants
}

\author{
Samuel Luiz Fioreze*, Cláudia Tochetto, \\ Antonio Eduardo Coelho, Heverton Fernando Melo
}

Federal University of Santa Catarina, Brazil.

*Corresponding author, e-mail: s.fioreze@ufsc.br

\begin{abstract}
This paper aims to evaluate the effects that calcium application on leaves and flowers of soybean plants exerts on yield and yield components. Two experiments were carried out in the $2013 / 2014$ crop season under field conditions. In the first experiment, two soybean cultivars one of determinate growth habit (BMX Ativa) and another of indeterminate growth habit (BMX Alvo) - were submitted to calcium spraying with four nozzles (twin flat, twin flat fan, cone and hollow cone). In the second experiment, soybean plants (BMX Ativa cultivar) were sprayed with calcium on the leaves and flowers at R1 or R3 growth stages. Subsequently, the plants were maintained or not under a 50-percent shade protection during flowering stage. Calcium spraying on soybean leaves or flowers during the flowering stage did not increase pod set, number of seeds, or grain yield. The calcium content in soybean flowers is not affected by foliar application thereof.
\end{abstract}

Keywords: flowering, foliar feeding, Glycine max, yield

\section{Introduction}

The occurrence of flower and pod abortion is commonly observed in soybean crops. Under normal growth conditions, the percentage of pod set varies from $20 \%$ to $40 \%$ (Kokubun, 2011), in a way that flowers with an abscission tendency show slower growth (Huff \& Dybing, 1980). Among the factors involved in the abscission control of soybean reproductive structures is the availability of photoassimilates and nutrients (Egli \& Bruening, 2006), as well as endogenous concentration of some plant hormones, such as absicic acid (ABA) and cytokinin (CK) (Nonokawa et al., 2007; Hirose et al., 2008).

The effects of calcium on flower fertilization include attraction, communication at short distances, cell fusion, and signaling. Scientific evidences suggest that calcium acts as a messenger in metabolic processes related to plant growth and development, such as cell division, differentiation, polarity and elongation; and plant photomorphogenesis, defense and response to biotic or abiotic stresses (Hong-Bo et al., 2008). Some models show that the intracellular flow of calcium and $\mathrm{H}^{+}$drives the growth of the pollen tube (Krichevsky et al., 2007). The first cell event observed after gametes fusion is the increase in cytosolic calcium concentration, followed by an increase in cellular division rate, which demonstrates its importance in the 
reproductive development of plants.

As an important nutrient for plant reproduction, the supply of calcium is often recommended as a possible way to increase flower set in soybean. In field, foliar application of calcium during the reproductive stage of soybean crops is usual among farmers. The results of foliar application of calcium in soybean plants, however, are not satisfactory or even consistent (Sevá \& Jorge, 1981; Quintana et al., 1996; Bevilaqua et al., 2002, Arantes et al., 2009; Fioreze, 2013; Fioreze et al., 2013; Seidel et al., 2015).

Calcium movement within the plant is restricted to apoplastic pathways, such as intercellular spaces and xylem (Write \& Broadley, 2003). Accepting the fact that soybean flowers have low transpiration rates (Write \& Broadley, 2003) and undeveloped functional xylem (Fioreze et al., 2017), calcium supply during the reproductive stage of soybean plants should have the flowers as main target, assuming that the nutrient that reaches the leaves will not be redistributed. In view of the above, the present paper aims to evaluate the effects that calcium supply on leaves and flowers exerts on soybean yield and yield components.

\section{Material and methods}

Two experiments were carried out under field conditions from November 2013 to March 2014. The experimental area is located in Curitibanos, state of Santa Catarina, Brazil (2716'26.55" S latitude and 50³0'14.41" W longitude of Greenwich and $988 \mathrm{~m}$ altitude). The climate of the region is the $\mathrm{Cfb}$ type, with average temperature between $15^{\circ} \mathrm{C}$ and $25^{\circ} \mathrm{C}$.

The first experiment was designed in randomized blocks using a split-spot scheme with four replications. The main plots consisted of two soybean cultivars, BMX Ativa (determinate growth) and BMX Alvo (indeterminate growth). The subplots consisted of the spraying of calcium on leaves using four different nozzles, besides a control treatment. Spray nozzles used were twin flat (110-02), twin flat fan (110-02), cone (80-02) and hollow cone (80-02). Each unit or subplot consisted of five rows with $5 \mathrm{~m}$ length, spaced $0.45 \mathrm{~m}$. The useful area was the three central rows, except for $1.0 \mathrm{~m}$ of each extremity, totaling $4.05 \mathrm{~m}^{2}$.

Sowing was carried out mechanically on November 10,2013, at a $4 \mathrm{~cm}$ depth with a seed drill, under no tillage system in succession to oat. Seeds were treated with Imidacloprid + Thiodicarb $\left(0.5 \mathrm{~L} 100 \mathrm{~kg}^{-1}\right)$ and Carbendazim + Thiram (0.2 L $\left.100 \mathrm{~kg}^{-1}\right)$ and inoculated with bacteria Bradyrhizobium japonicum (100g 100kg ') immediately before sowing. Soil chemical properties were: organic matter, $28 \mathrm{~g} \mathrm{dm}-3$; $\mathrm{pH}\left(\mathrm{CaCl}_{2}\right)$, 6.3; $\mathrm{Ca}, 83.5$ mmolc dm-3; $\mathrm{Mg}, 41$ mmolc dm-3; Al, $0.0 \mathrm{cmolc} \mathrm{dm}^{-3} ; \mathrm{K}, 10 \mathrm{mmolc}$ dm-3; P (Mehlich 1), $10.7 \mathrm{mg} \mathrm{dm}^{-3}$; and $72 \%$ base saturation. Fertilizers were applied at rates of 70 $\mathrm{Kg} \mathrm{ha}^{-1} \mathrm{~K} 2 \mathrm{O}$ and $70 \mathrm{Kg} \mathrm{ha}^{-1} \mathrm{P}_{2} \mathrm{O}_{5}$. Sowing densities were 350 thousand seeds $\mathrm{ha}^{-1}$ for BMX Ativa cultivar and 330 thousand seeds ha $^{-1}$ for BMX Alvo cultivar.

Weed control was performed at 20 days after emergence (DAE), through sequential application of Glyphosate (1,5 L ha-1) and Bentazon (1,2 $\mathrm{L} \mathrm{ha}^{-1}$ ) with a 10-day interval. At the R1 and R5 growth stages (Fehr \& Caviness, 1977), pests and diseases control was performed with insecticide Imidacloprid + $\beta$-cyfluthrin ( $1 \mathrm{~L} \mathrm{ha}^{-1}$ ) and fungicide Azoxystrobin + Cyproconazole $\left(300 \mathrm{ml} \mathrm{ha}^{-1}\right)$. The average rainfall during the experiment period is displayed in Figure 1.

Foliar calcium spraying was performed at the R2 growth stage (Fehr \& Cavinnes, 1977), characterized by full flowering of the crop. Calcium was applied at a rate of $235.8 \mathrm{~g} \mathrm{ha}^{-1}$, which corresponds to the recommended rate of this commercial product (Stoller $\mathrm{Cálcio}^{\circledR}$ ) for soybean crops. The application was performed using a sprinkler with a spray bar under $\mathrm{CO}_{2}$ pressure, adjusted to a spray volume of $150 \mathrm{~L} \mathrm{ha}^{-1}$. The adjuvant used was $0.5 \%$ vegetable oil. During application, the temperature remained between 20 and $25^{\circ} \mathrm{C}$, with relative humidity between $70 \%$ and $80 \%$, and low wind.

After the sprayed product dried, the flowers were collected from the upper, middle and lower thirds of the plants to determine the calcium content (Tedesco et al., 1995). Plants were collected at 120 DAE. Yield components were obtained from 15 plants per subplot, which were divided into lower, middle and upper thirds. 


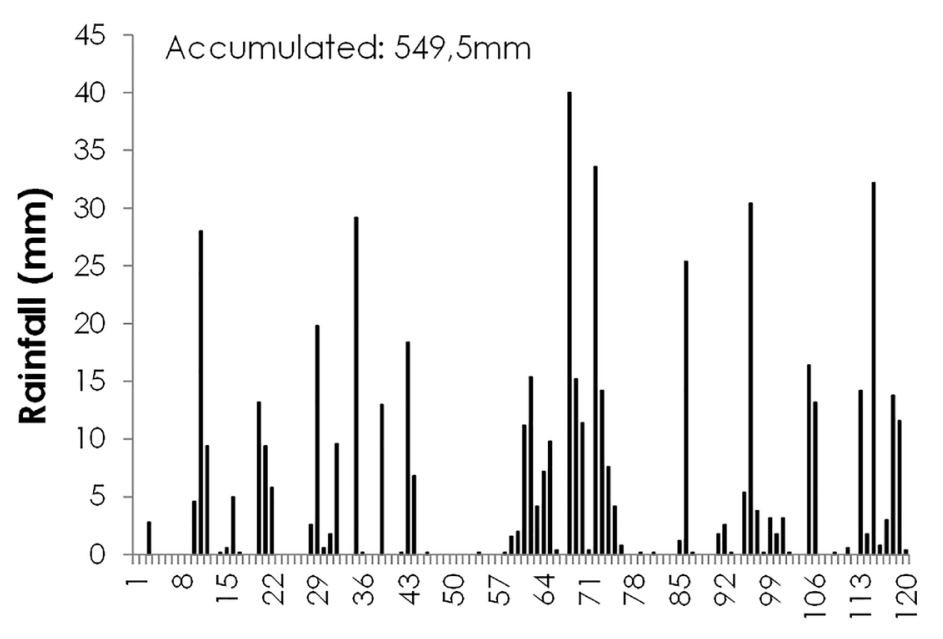

\section{Days after emergence}

Figure 1. Rainfall during the soybean growing season. Curitibanos (SC), Brazil, 2014

The yield components were separated into number of pods, viable pods, number of grain per pod, and yield per plant. After harvesting, yield and a thousand grain yield were evaluated, adjusting the values to $13 \%$ moisture. The data were subjected to analysis of variance $(p<0.05)$ using the Sisvar ${ }^{\circledR}$ software, and the means were separated using Student's t-test $(p<0.05)$.

The second experiment was designed in randomized blocks using a split-spot scheme with four replications. The main plots consisted of two environmental conditions (full sun and 50-percent shade protection during 10 days after the Rl stage). The subplots consisted of targeted application of calcium on leaves and flowers at the R1 and R3 stages, besides a control treatment. Each unit or subplot consisted of five rows with $1 \mathrm{~m}$ length, spaced $0.45 \mathrm{~m}$. The useful area was the three central rows, totaling $2.25 \mathrm{~m}^{2}$. The soybean cultivar used was BMX Ativa.

Sowing was carried out manually on November 15, 2013, at a $4 \mathrm{~cm}$ depth, under a conventional tillage system. Seed treatment and inoculation were performed as described previously. Soil chemical properties were: organic matter, $69.7 \mathrm{~g} \mathrm{dm}^{-3} ; \mathrm{pH}\left(\mathrm{CaCl}_{2}\right), 5.9 ; \mathrm{Ca}, 83 \mathrm{mmol}_{\mathrm{c}}$ $\mathrm{dm}^{-3} ; \mathrm{Mg}, 73 \mathrm{mmol}_{\mathrm{c}} \mathrm{dm}^{-3} ; \mathrm{Al}, 0.0 \mathrm{cmol}_{\mathrm{c}} \mathrm{dm}^{-3} ; \mathrm{K}, 23$ $\mathrm{mmol}_{\mathrm{c}} \mathrm{dm}^{-3}$; P (Mehlich 1), $17.34 \mathrm{mg} \mathrm{dm}^{-3}$; and $80.7 \%$ base saturation. Fertilizers were applied at rates of $14 \mathrm{Kg} \mathrm{ha}^{-1} \mathrm{~N}, 28 \mathrm{Kg} \mathrm{ha}^{-1} \mathrm{~K}_{2} \mathrm{O}$ and $63 \mathrm{Kg} \mathrm{ha}^{-1}$ $\mathrm{P}_{2} \mathrm{O}_{5}$. At the VC stage (Fehr \& Caviness, 1977), plant density was adjusted to 15 plants per meter by thinning. In order to limit the competition between primary and secondary branches of plants, secondary stem primordia were manually removed, resulting in plants with the main stem, only.

The plants were kept under the same conditions until the R1 stage (Fehr \& Caviness, 1977). Total photosynthetic active radiation was reduced to $50 \%$ by means of a shade cloth protection positioned one meter above the canopy of the plants (Figure 2). After ten days of shading, the protection was removed, and all treatments were conducted under full sun conditions until the end of the crop cycle.

Calcium application on leaves was performed as previously described, using a twin flat spray nozzle (1 10-02). Calcium application on flowers was performed using a sprinkler, with the same calcium solution used on leaves. In both stages, the application was performed early in the morning. At the end of the crop cycle, yield and yield components were evaluated as described for the first experiment. The data were subjected to analysis of variance $(p<0.05)$ using the Sisvar ${ }^{\circledR}$ software, and the means were separated using Student's t-test $(p<0.05)$.

\section{Results and discussion}

Foliar application of calcium at the flowering stage of the plants did not affect pod set, grain mass per plant, or grain yield for the soybean cultivars tested, regardless of the spray nozzle used (Table 1). Differences in yield components were observed only among soybean cultivars, which were already expected. 


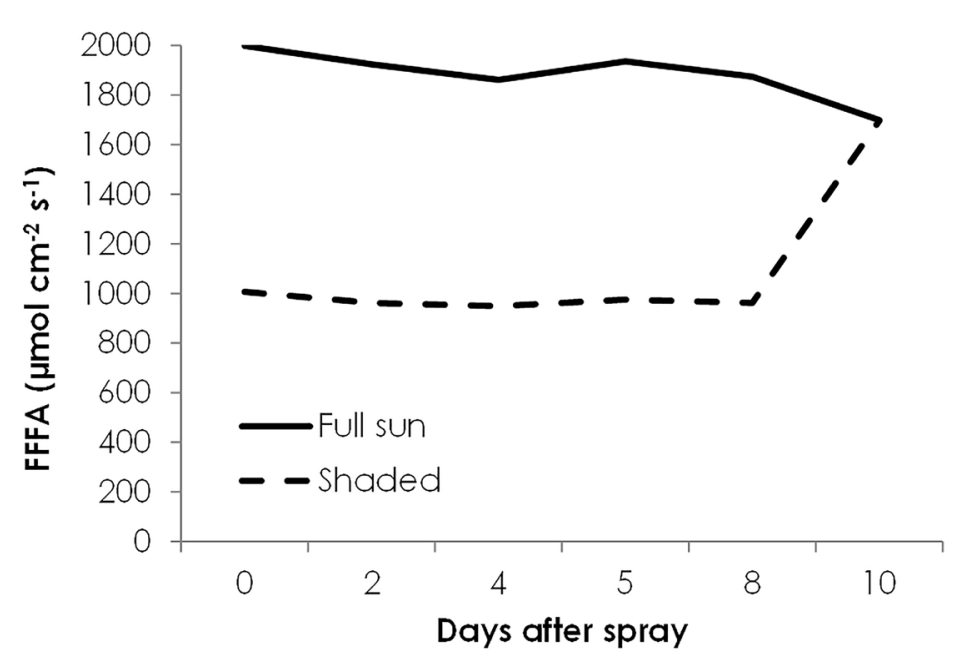

Figure 2. Photosynthetic active radiation during the evaluation period of the soybean plants submitted to Calcium spraying. Curitibanos (SC), Brazil, 2014

Table 1.Yield and yield components of two soybean cultivars regarding calcium spraying on leaves using four nozzles. Curitibanos (SC), Brazil, 2014.

\begin{tabular}{|c|c|c|c|c|c|c|c|}
\hline Nozzles & YIELD & TGM & NP & NVP & $\% \vee P$ & NG & NGP \\
\hline Control & 3309.7 & 157.6 & 50.4 & 46.5 & 92.4 & 109.0 & 2.4 \\
\hline Cone & 3543.0 & 159.3 & 49.9 & 45.9 & 92.1 & 106.8 & 2.3 \\
\hline Hollow cone & 3371.1 & 156.6 & 54.2 & 49.8 & 92.0 & 117.3 & 2.4 \\
\hline twin flat & 3410.5 & 160.2 & 50.3 & 46.9 & 93.2 & 111.9 & 2.4 \\
\hline twin flat fan & 3303.5 & 162.8 & 52.3 & 47.8 & 91.4 & 111.3 & 2.3 \\
\hline $\mathrm{CV}(\%)$ & 12.63 & 6.76 & 12.31 & 13.29 & 3.55 & 14.93 & 4.37 \\
\hline $\mathrm{Pr}>\mathrm{FC}$ & 0.74 & 0.59 & 0.61 & 0.76 & 0.81 & 0.75 & 0.72 \\
\hline Cultivar & YIELD & TGM & NP & NVP & $\% \vee P$ & NG & NGP \\
\hline BMX Ativa & $3549.4 \mathrm{a}$ & 157.3 & 52.2 & 48.1 & 92.2 & 110.8 & $2.30 \mathrm{~b}$ \\
\hline BMX Alvo & $3225.7 \mathrm{~b}$ & 161.4 & 50.6 & 46.6 & 92.3 & 111.7 & $2.40 \mathrm{a}$ \\
\hline CV (\%) & 9.74 & 5.04 & 11.35 & 10.89 & 3.04 & 12.75 & 3.86 \\
\hline $\mathrm{Pr}>\mathrm{FC}$ & 0.02 & 0.11 & 0.41 & 0.47 & 0.91 & 0.86 & 0.00 \\
\hline
\end{tabular}

Thus, the highest grain yield was observed for BMX Ativa cultivar.

The calcium content in flowers from three thirds of the soybean plants, under field conditions, was not affected by foliar spraying with the nutrient, irrespective of the spray nozzle used (Table 2). There was low variation in calcium levels between the treatments, contrary to what was expected. Flowers in racemes from the upper third of the soybean plants are closer to the spray bar, with less coverage of the leaves in relation to the others, thus becoming a target with greater probability of being reached. This, however, was not observed in the present study, since the foliar application did not even affect the calcium content of the flowers from the upper third of the plants. This indicates that foliar application is not efficient in providing the nutrient to the soybean flowers.
The targeted application of calcium on leaves or even on flowers did not affect pod set and other yield components of soybean plants in the second experiment, in the two application stages and the environment tested (Table 3). Considering that the calcium that reaches the leaves would unlikely be remobilized, the primary objective of calcium application should be a direct supply to reproductive structures showing undeveloped functional xylem (Mondal et al., 2011; Fioreze et al., 2017). The targeted application of calcium on the flowers aimed to isolate the umbrella effect provided by the leaves of the plant, to ensure that the nutrient reached the target, that is, the flowers. After a direct contact between calcium and flowers, positive effects on pollen tube growth or even on cell division could be expected, resulting in an increase in the number of pods or even grains 
Fioreze et al. (2018) / Effects of calcium supply...

Table 2. Calcium content in soybean flowers (BMX Ativa) after foliar calcium spraying using four nozzles. Curitibanos (SC), Brazil, 2014.

\begin{tabular}{cccc}
\hline & Lower third & Middle third & Upper third \\
\hline & & $\mathrm{g} \mathrm{kg}^{-1}$ & \\
\hline Control & 6.97 & 8.00 & 8.17 \\
Cone & 6.72 & 7.59 & 7.90 \\
Hollow cone & 7.07 & 8.17 & 7.88 \\
twin flat & 9.02 & 8.03 & 8.31 \\
twin flat fan & 7.32 & 7.90 & 7.52 \\
\hline CV(\%) & 4.25 & 3.16 & 3.54 \\
\hline Pr>FC & 0.15 & 0.94 & 0.91 \\
\hline
\end{tabular}

Table 3. Yield components of soybean (BMX Ativa) regarding calcium spraying on leaves and flowers at the R 1 or R3 growth stages. Curitibanos (SC), Brazil, 2014.

\begin{tabular}{ccccccc}
\hline Calcium spraying & GM & NP & NVP & \%VP & NG & NGP \\
\hline Control & 12.1 & 37.4 & 35.3 & 94.1 & 87.7 & 2.3 \\
Leaves at R1 & 10.6 & 32.5 & 31.2 & 95.9 & 75.7 & 2.3 \\
Leaves at R3 & 12.6 & 38.8 & 37.1 & 95.3 & 92.1 & 2.4 \\
Flowers at R1 & 11.5 & 39.3 & 37.7 & 95.9 & 90.5 & 2.3 \\
Flowers at R3 & 12.2 & 39.6 & 37.7 & 94.8 & 92.8 & 2.3 \\
\hline CV (\%) & 17.03 & 19.02 & 19.65 & 1.92 & 19.78 & 4.46 \\
\hline Pr>Fc & 0.87 & 0.57 & 0.61 & 0.23 & 0.71 & 0.75 \\
\hline Environment & GM & NP & NVP & $\%$ VP & NG & NGP \\
\hline Full sun & 12.0 & 38.2 & 36.2 & 94.6 & 89.1 & 2.3 \\
Shaded & 11.5 & 36.9 & 35.3 & 95.8 & 86.5 & 2.3 \\
\hline CV (\%) & 18.23 & 30.24 & 31.58 & 2.27 & 32.28 & 1.11 \\
\hline Pr>FC & 0.51 & 0.74 & 0.82 & 0.19 & 0.79 & 0.09 \\
\hline GM: grain mass per plant (g); NP: number of pods per plant; NVP: number of viable pods per plant; \%VP: percentage of viable pods; NG: number \\
of grains per plant; NGP: number of grains per pod. & & & & &
\end{tabular}

per plant. This effect should be observed mainly on applications at the Rl stage, because the fecundation of soybean flowers occurs at least two days before complete opening of petals, and full opened flowers show embryos with first cell divisions (Fioreze et al, 2017)

Calcium is classified as immobile in plants, with movement restricted to apoplastic spaces, such as intercellular spaces and xylem. The movement of calcium by this way is dependent on the transpiratory flow, which is often low in young tissues (Gilliham et al., 2011). Considering that the long-distance transport of calcium is limited to xylem vessels, a limitation in the calcium supply in a shaded environment could also be expected, which would be caused by the reduction in the transpiration rate. This could result in greater abscission of flowers. In this context, targeted application of calcium on flowers should result in positive effects. However, neither results were not observed.

Considering the traits of nutrients and plants, the targeted application of calcium in the reproductive structures of soybean crops can be seen as a challenge in terms of application technology. Soybean plants show high leaf area index (LAI) after the beginning of the flowering period (Heiffig et al., 2006), which makes the spray deposition difficult, even on leaves from middle and lower thirds. Due to their location, flowers from the lower third of soybean plants are even harder to be reached. In the first experiment, LAI values were 3.2 and 2.9 for BMX Ativa and BMX Alvo soybean cultivars, respectively.

The results obtained in this study show that foliar calcium application, at the recommended doses, is not efficient in improving nutrient supply in flowers through the canopy of soybean plants, not even yield, irrespective of the spray nozzle used. Additionally, the main recommended spray nozzles for the crop were used (for herbicides, fungicides and insecticides). Better drop deposition in the upper third of soybean plants was observed by Viana et al. (2008) using twin flat or hollow cone nozzles, while twin flat fan nozzles provided greater coverage throughout the canopy of the crop. Cunha et al. (2006) observed that twin flat fan nozzles provided 
greater coverage throughout the canopy of soybean crops. These studies, however, evaluated spray deposition just on leaves, which does not imply that flowers are reached.

In the present study, the umbrella effect caused by the leaves was isolated through the targeted application of calcium on the flowers. Thus, the lack of results allows us to question the efficiency of calcium supply in soybean crops. Our results are in line with the results obtained by other authors, who did not observe positive effects for calcium supply during the reproductive stage of soybean or even bean crops.

During the last decades, several authors (Sevá \& Jorge, 1981; Quintana et al., 1996; Bevilaqua et al., 2002, Arantes et al., 2009; Fioreze et al., 2013; Seidel et al., 2015; Fioreze et al., 2017) have proposed to evaluate the effects of foliar calcium application as a strategy to increase the productive efficiency of crops, such as soybeans and beans, which are known to have high rates of abscission of reproductive structures. The motivation of those studies, in part, is the frequent recommendation of foliar application of calcium or boron by the companies that commercialize these products. A positive effect of the application of these nutrients, as demonstrated by the studies cited and the results obtained in the present study, seems not to exist. In this way, it is clear that the abscission of flowers and pods in soybean plants is associated with other factors, such as the hormonal balance and the availability or capacity of use of assimilates by the plants (Liu et al., 2004a; Liu et al., 2004b; Nonokawa et al., 2007; Faquir et al., 2011).

\section{Conclusions}

1- $\quad$ Foliar calcium spraying at the full flowering stage did not affect yield components, and final yield of the soybean crop.

2- $\quad$ Foliar calcium spraying at the full flowering stage did not affect the calcium content in flowers of the soybean crop.

3- Calcium spraying on buds or opened flowers did not affect yield components of the soybean crop.

\section{References}

Arantes, R.P., Cury, T.N., Leão, F.P. 2009. Aplicação foliar de cálcio e boro a base de cloreto de cálcio e ácido bórico misturado no tanque para avaliação de rendimento da semente de soja. Nucleus 6: 117-121.

Bevilaqua, G.A.P., Silva Filho, P.M., Possenti, J.C. 2002. Aplicação foliar de cálcio e boro e componentes de rendimento e qualidade de sementes de soja. Ciência Rural 32: 31-34.

Cunha, J.P.A.R. da, Reis, E.F. dos., Santos, R. de O. 2006. Controle químico da ferrugem asiática da soja em função de ponta de pulverização e de volume de calda. Ciência Rural 36: 1360-1366.

Egli, D.B., Bruening, W.P. 2006. Temporal profiles of pod production and reproductive success in soybean. European Journal of Agronomy 24: $11-18$.

Fakir, M.S.A., Mondal, M.M.A., Ismail, M.R.,Ashrafuzzaman, M. 2011. Flowering pattern and reproductive efficiency in mungbean. International Journal of Agriculture \& Biology 13: 966-970.

Fehr, W.R., Caviness, C.E. 1977.Stages of soybean development. Ames: State University of Science and Technology, 11 p. (Special report, 80).

Fioreze, S.L., Rodrigues, J.D., Carneiro, J.P.C., Silva, A.A., Lima, M.B. 2013. Fisiologia e produção da soja tratada com cinetina e cálcio sob déficit hídrico e sombreamento. Pesquisa Agropecuária Brasileira 48: 1432-1439.

Fioreze S.L., Carneiro, J.P.C., Pinto, D. D., Rodrigues, J.D. 2017. Foliar application of calcium and kinetin on soybean at reproductive stage. Journal of plant nutrition 40: 1 -9.

Gilliham, M., Dayod, M., Hocking, B.J., XU, B., Conn, S.J., Kaiser, B.N., Leigh, R.A., Tyerman, S.D. 2011. Calcium delivery and storage in plant leaves: exploring the link with water flow. Journal of Experimental Botany 62: 2233-2250.

Heiffig, L.S., Câmara, G.M. de S., Marques, L.A., Pedroso, D.B., Piedade, S.M. de S. 2006. Fechamento e índice de área foliar da cultura da soja em diferentes arranjos espaciais. Bragantia 65: 285-295.

Hirose, N., Takei, K., Kuroha, T., KamadaNobusada, T., Hayashi, H., Sakakibara, H. 2008. Regulation of cytokinin biosynthesis, compartmentalization and translocation. Journal of Experimental Botany 59: 75-83.

Hong-Bo, S., Li-Ye, C., Ming-An, S. 2008. Calcium as a versatile plant signal transducer under soil water stress. BioEssays 30: 634-641.

Huff, A., Dybing, C.D. 1980. Factors affecting shedding of flowers in soybean [Glycine max (L.) Merrill]. Journal of Experimental Botany 31: 51-62. 
Kokubun, M. 2011. Physiological Mechanisms Regulating Flower Abortion in Soybean. In: Ng, T.B. (Ed.). Soybean biochemistry, chemistry and physiology. Janeza Trdine, Rijeka, Croatia. p. 541554.

Krichevsky, A., Kozlovsky, S.V., Tian, G., Chen, M., Zaltsman, A., Citovsky, V. 2007. How pollen tubes grow. Developmental Biology 303: 405-420.

Liu, F., Jensen, C.R., Andersen, M.N. 2004a.Pod Set Related to photosynthetic rate and endogenous $A B A$ in soybeans subjected to different water regimes and exogenous $A B A$ and $B A$ at early reproductive stages. Annals of Botany 94: 405411.

Liu, F., Jensen, C.R., Andersen, M.N. 2004b. Drought stress effect on carbohydrate concentration in soybean leaves and pods during early reproductive development: its implication in altering pod set. Field Crops Research 86:1-13.

Mondal, M.M.A., Fakir, M.S.A., Azad-Ud-Doula Prodhan, A.K.M., Ismail, M.R., Ashrafuzzaman, M. 2011. Deflowering effect on vasculature and yield attributes in raceme of mungbean [Vigna radiata (L.) Wilczek]. Australian Journal of Crop Science 5: 1339-1344.

Nonokawa, K., Kokubun, M., Nakajima, T., Nakamura, T., Yoshida, R. 2007. Roles of Auxin and Cytokinin in Soybean Pod Setting. Plant Production Science 10: 199-206.

Quintana, J.M., Harrison H.C., Nienhuis, J., Palta J.P., Grusak, M.A. 1996. Variation in calcium concentration among sixty S1 families and four cultivars of snap bean (Phaseolus vulgaris L.). Journal of the American Society for Horticultural Science 121: 789-793.

Seidel, E.P, Egewarth, W.A., Piano, J.T.V, Egwarth, J. 2015. Effect of foliar application rates of calcium and Boron on yield and yield attributes of soybean (Glycine max). Research African Journal of Agricultural 10:170-173.

Sevá, S.S., Jorge, J.P.N. 1981. Aplicação de cálcio por via foliar na produção de grãos de soja. Bragantia 40: 185-188.

Tedesco, M.J., Gianello, C., Bissani, C.A., Bohnen, H., Volkweiss, S.J. 1995. Análise de solo, plantas e outros materiais. $2^{a}$ ed. Porto Alegre, Departamento de Solos da Universidade Federal do Rio Grande do Sul. 174p. (Boletim Técnico de Solos, 5)

Viana, R.G., Ferreira, L.R., Teixeira, M.M., Cecon, P.R., Souza, G.V.R. de. 2008. Deposição de gotas no dossel da soja por diferentes pontas de pulverização hidráulica e pressões de trabalho. Engenharia na Agricultura 16: 428- 435.
White, P.J., Broadley, M.R. 2003.Calcium in plants. Annals of Botany 92:487-51 1. 